\title{
Knowledge, Awareness and Perception of National Gas Policy (NGP) 2017 among Oil and Gas Legal Experts in Nigeria
}

\author{
Dr Temilade O. Jolaosho \\ Debbiesam Consults, \\ Ibadan, Nigeria. \\ DOI: $10.31364 / \mathrm{SCIRJ} / \mathrm{v} 8.14 .2020 . P 0420768$ \\ http://dx.doi.org/10.31364/SCIRJ/v8.i4.2020.P0420768
}

\begin{abstract}
Knowledge and experience are intrinsically connected. Studies have generally shown that knowledge, awareness and perceptions are directly proportional to the skills and experience of individuals in their respective disciplines. Propped on the theory of epistemology, this study was aimed at assessing the knowledge, awareness and perceptions of the oil and gas legal experts on the National Gas Policy (NGP) 2017. The knowledge assessment was carried out by comparing the correlation between academic qualification and years of experience of the experts on the Nigerian policy framework of the gas sector (with emphasis on the NGP 2017). The study highlights the attempts of the present policy framework at reducing gas flaring. Furthermore, the study found that there is no significant relationship between the years of experience and the knowledge of oil and gas experts on the NGP 2017, as some with less years of experience were found to be more knowledgeable about the policy. The existing gap in knowledge could be attributed to the absence of an in-depth knowledge of the oil and gas legal experts on some aspects of NGP 2017. The study therefore suggests a possible inclusion of advanced education on market based instruments in environmental law curriculum subsequently.
\end{abstract}

Index Terms - Gas flaring, National Gas Policy 2017, Oil and gas legal experts, years of experience, knowledge.

\section{INTRODUCTION}

The National Gas Policy is comprised of initiatives by the Federal Government of Nigeria to address the nation's gas sec tor issues. This initiative commenced amongst other things, wit h the Natural Gas Strategy in 2003, National Gas Policy 2004, Gas Master Plan (GMP) 2008; and legislations such as t he Nigerian Domestic Gas Supply and Pricing Regulations and the Petroleum Industry Bill [1]. The policy substituted the GMP which previously made provision for the enlargement of the internal gas market. Nigeria has not been deficient with re ference to policy initiatives, however, lots of the policies are yet to be transmuted into laws.

The National Gas Policy 2017 is a robust compendium of Nigeria's past policies aimed at phasing out gas flaring within the past thirteen years. At the policy level in Nigeria, it appears that the strength of the present framework consisting of the National Gas Policy 2017, the National Petroleum Policy 2017 and the National Petroleum Fiscal Policy 2017, lies in the fact that they have aspects of market instruments incorporated within them; which instruments are inter alia, targeted at reducing gas flaring. The policy maps out government's goals for the gas sector and sets goals, strategies and plans for the introduction of an appropriate context to resolve hiccups with present investment in the sector [2].

Gas flaring has been defined as the controlled burning of Natural gas trapped with oil reserves in the ground and released and extracted along with crude oil from the ground [3]. It is the practice of burning off unwanted and unutilised associated gases that are extracted from the inner parts of the earth along with crude oil [4]. Gas flaring has remained uniquely branded as a singular foremost origin of ecological pollution in the Niger Delta region [5]. The Niger Delta region is the nucleus of Nigeria's oil and natural gas resources. Nigeria has estimated natural gas reserves of approximately 180.5 trillion cubic feet (tcf) and 37.1 billion barrels of proven crude oil reserves with a production capacity of 2.4 million barrels per day [6].

Although natural gas is Nigeria's most dominant natural resource and it is regarded as a gas province with some oil in it [7], the utilisation of gas within the country is nevertheless $i$ $\mathrm{n}$ complete and the massive gas reserves are underutilised duet o poor gas infrastructure and the absence of a resilient gas market [8]. The U.S Energy Information Administration stated that Nigeria was ranked the fifth highest natural gas flaring country, with a diminution from the second position it held in 2011 [9].

Presently, Nigeria has been ranked the seventh highest ga $\mathrm{s}$ flaring nation in the world. In order to achieve the national mandate for flare out policy by 2020, the National Gas Policy 2017 introduced commercialisation of flared gas for supply into the domestic market. This has been a strategic priority focus of the federal government, through the ongoing Nigeria Gas Flare Commercialisation Program (NGFCP) initiated by the Minister of Petroleum Resources on December 13, 2016. The Federal Government had initiated diverse actions to reaffirm its commitment to putting an end to gas flaring and partaking in emission reductions in line with the provisions of the national policy on the environment and the Paris Agreement. Precisely, the commitment was demonstrated by the ratification of the Paris Agreement of 2015, signing of the Global Gas Flaring Partnership (GGFP) principles for global flare-out by 2030 , while committing to a national flare-out target by the 
year 2020 and the launching of the National Gas Flare Commercialisation Programme (NGFCP) [10].

This paper contends that the NGP is not a rehash of earlier gas policies, as it introduces new dimensions into the regulation of oil and gas operations in Nigeria. With reference to the commercial framework the NGP seeks to bring on board a network code and gas swaps respectively. The network code would allow access to all midstream facilities. The National Gas Flare Commercialisation Programme (NGFCP), a trade measure, initiated in Nigeria by the federal government, to regulate gas flaring by commercialising the gas, is a typical example of a market instrument. Market based instruments are intelligent means of regulation, which amongst other things, are designed to ensure efficacy in achieving environmental outcomes. Organisation for Economic Cooperation and Development provided a compilation of diverse cost effective instruments [11].

Another example of market instrument proposed under th e National Gas Policy is the 'gas swap arrangement.' This is a commercial arrangement between the federal government and the international oil companies (IOCs) engaged in oil and gas operations in Nigeria. The arrangement would encourage market players to develop their market positions. However, o nly market players who have met their domestic gas supply o bligations (DGSO) would be allowed to engage in the commercial gas swap arrangement. It is instructive to note that the DGSO is an authorised obligation to the national gas market; whereby gas producers are to set aside, a fixed percentage of gas produced for supplying the local market.

The National Gas Policy seeks to ensure that flared gas is utilised in markets. To culminate these efforts, procedures to ensure that flare seizure and utilisation projects are developed and will work collaboratively with industry development partners, providers of flare-capture technologies and third party investors have been taken by government. To a large extent, one can state that the policy framework has significantly led to a reduction of the amount of gas flaring, hitherto experienced in Nigeria. This is so because only about 800.59 million standard cubic feet per day was flared from September 2017 to September 2018[12]. The study therefore highlights $t$ he attempts of the present policy framework at reducing gas $\mathrm{fl}$ aring and a knowledge assessment was carried out by comparing the correlation between academic qualification and years of experience of selected experts on the Nigerian gas policy framework.

The National Petroleum Policy is to be implemented alongside the National Gas Policy and the National Petroleum Fis cal Policy. The National Petroleum Policy provides the legal, regulatory, institutional, commercial, fiscal and operational framework for the oil and gas sector. It is instructive to note that the fiscal provisions of the policies provide incentives and tax rates and tax exemptions, which are generally to encourage a change in behavior of international oil companies engaged in oil and gas operations, towards environmentally sustainable outcomes.

Fundamentally, gas flare legislation and anti-flare policies are the conventional tools which have been used to discourage gas flaring. The policies however have not exactly discourageed gas flaring. With reference to the policies, the paper contends that one cannot talk in terms of discouragement of gas flaring. The aims of the policies are to phase out gas flaring com pletely through encouraging gas utilisation projects and to meet the flare out target of 2020 .

\section{MATERIALS AND METHODS}

The methodology adopted by this study was doctrinal. Doctrinal approach entails an analysis of the legal structure, legal $f$ ramework of the subject matter and case laws [13]. The doctrinal approach was complemented with the use of key informant interviews (KII) and questionnaire. The choice of this approach was for the purpose of getting first hand information on gas flaring from key stakeholders. Officers in the Department of Petroleum Resources, Nigerian National Petroleum Corporation an $\mathrm{d}$ legal experts that had been involved in the formulation of $\mathrm{ga}$ s policies and negotiation of oil and gas utilisation projects and deals, were interviewed.

The primary sources consulted were the Constitution of the Federal Republic of Nigeria 1999 (as amended) and various statutes regulating the gas sector in Nigeria such as Flare Gas (Prevention of Waste and Pollution) Regulations 2018, Associated Gas Re Injection Act 2004, Associated Gas Re Injection (Continued Flaring of Gas) Regulations 2004. The policies consulted were the National Gas Policy 2017, the National Petrol eum Policy 2017, National Policy on the Environment 2017 a nd the National Petroleum Fiscal Policy 2017.

Secondary sources consulted were relevant law text-books, proceedings of national and international conferences, peerreviewed journals, annual reports of multinational oil companies, newspaper reports, reported cases and internet materials related to the subject matter. Qualitative and quantitative research designs were used. The aim of the qualitative approach was to achieve an in-depth understanding of various participants' experiences and from the data, well validated co nclusions were produced, which corroborated the informat-ion from the survey.

\section{A. Study Population and Sampling}

Sampling refers to the process used to select a portion of the population for study. Qualitative research is generally based 0 n non probability and purposive sampling. Purposive sampling means that participants were selected because of some defining characteristics that make them holders of the data needed for the study [14].

For the purpose of the study, purposive sampling was applied. A search engine hg.org legal resources was engaged. Hg.org is one of the very first online law and government sites founded in 1995. The sample frame was drawn from the Nigeria National Petroleum Corporation Abuja, Department of Petroleum Resources, Lagos and some leading oil and gas legal consultants in Lagos, precisely Lekki, Victoria Island and I koyi areas. Firms such as Advisory Legal Consultants (ALC), Lekki, who prepared the National Gas Policy 2004, and which firm also negotiated the first gas supply transaction under the National Gas Master Plan (NGMP) were visited. Others were Century Energy Ltd. Lekki, AELEX Legal Practitioners and Arbitrators, Ikoyi, Templars, Victoria Island and Streamsowers and Kohns Legal Practitioners and Arbitrators, Victoria Island, who all provided the richest possible sources of inform -ation. 


\section{B. Data Collection}

For this study, the data collection technique was through key informant interviews (KII) with the participants and administration of a questionnaire. Prior to conducting interviews, the informed consent of the participants were obtained in line with the requirements of the University of Ibadan Social Science and Humanities Research Ethics Committee (SSHREC) which reviewed and gave full ethical approval for the study. Data collected from the questionnaire were entered into a Statistical Package for Social Sciences (SPSS) version 23. C hi square test was carried out to explore the correlation between the independent and dependent variables.

\section{RESULTS}

A total number of twenty six (26) questionnaires were administered over a 6 week period and at the end of the exercise, twenty (20) questionnaires were retrieved, demonstrating a response rate of $76.9 \%$. There was an equal distribution of participants in the study (males and females were $50.0 \%$ each). Si xty per cent were private practitioners while $40.0 \%$ were public servants. Majority (65.0\%) had Master of Laws degrees (LL.M). Four (4) key informant interviews (KII) were conducted; two were with management cadre officials of the Department of Petroleum Resources, Lagos and the other two were principal consultants of private oil and gas legal firms in Lagos. The demographic data are tabulated in Table 1 .

TABLE I. DEMOGRAPHIC CHARACTERISTICS OF RESPONDENTS

\begin{tabular}{|c|c|c|c|}
\hline \multirow{2}{*}{$\begin{array}{l}\text { Table } \\
\text { Head }\end{array}$} & \multicolumn{3}{|c|}{ Demographic Characteristics } \\
\hline & Variables & Frequency & Percentage \\
\hline \multirow[t]{2}{*}{ Gender } & Male & 10 & 50.0 \\
\hline & Female & 10 & 50.0 \\
\hline Total & & 20 & 100.0 \\
\hline \multirow[t]{3}{*}{ Age } & 20-29years & 3 & 15.0 \\
\hline & $30-49$ & 14 & 70.0 \\
\hline & $50-59$ & 3 & 15.0 \\
\hline Total & & 20 & 100.0 \\
\hline \multirow[t]{6}{*}{$\begin{array}{l}\text { Years } \\
\text { of Expe } \\
\text {-rience }\end{array}$} & $0-5$ & 8 & 40.0 \\
\hline & $6-10$ & 7 & 35.0 \\
\hline & $11-15$ & 1 & 5.0 \\
\hline & $16-20$ & 2 & 10.0 \\
\hline & $21-25$ & 1 & 5.0 \\
\hline & 26 and above & 1 & 5.0 \\
\hline Total & & 20 & 100.0 \\
\hline $\begin{array}{l}\text { Highest } \\
\text { Qualifi- } \\
\text { cation }\end{array}$ & LL.B/ B.L & 5 & 25.0 \\
\hline
\end{tabular}

\begin{tabular}{|c|c|c|c|}
\hline \multirow{2}{*}{$\begin{array}{l}\text { Table } \\
\text { Head }\end{array}$} & \multicolumn{3}{|c|}{ Demographic Characteristics } \\
\hline & Variables & Frequency & Percentage \\
\hline & LL.M & 13 & 65.0 \\
\hline & $\mathrm{Ph} . \mathrm{D}$ & 1 & 5.0 \\
\hline & Others & 1 & 5.0 \\
\hline Total & & 20 & 100.0 \\
\hline \multirow[t]{2}{*}{$\begin{array}{l}\text { Place } \\
\text { of work }\end{array}$} & Private Practitioners & 12 & 60.0 \\
\hline & Public Servants & 8 & 40.0 \\
\hline Total & & 20 & 100.0 \\
\hline \multirow[t]{4}{*}{$\begin{array}{l}\text { Rank } \\
\text { of } \\
\text { Respon } \\
\text {-dent }\end{array}$} & Management Cadre & 6 & 30.0 \\
\hline & Consultant & 8 & 40.0 \\
\hline & Intermediate Cadre & 4 & 20.0 \\
\hline & Junior Cadre & 2 & 10.0 \\
\hline Total & & 20 & 100.0 \\
\hline
\end{tabular}

\section{A. Awareness of the Policies and the extent to which they} discourage Gas Flaring

In response to the ways the policies have discouraged gas flaring in Nigeria, one of the Management Officials interviewed at the Department of Petroleum Resources (DPR) Headquarters, Lagos stated that: "The policies have not discouraged gas flaring in Nigeria. With reference to the policies, you cannot talk in terms of discouragement. The aims of the policies are to reduce gas flaring. To a large extent, they have significantly reduced the amount of gas flaring hitherto experienced in Nigeria." However, another interviewee, a Principal Consultant at one of the oil and gas advisory firms visited said: "The policies have discouraged gas flaring basically by seeking to phase out gas flaring completely through encouraging gas utilisation projects and ensuring total flare out target is met by 2020.” There was a general consensus among the interviewees that the National Gas Policy (NGP) 2017 is the current/ most recent policy on gas in Nigeria. Those interviewed were of the opinion that the NGP 2017 is a comprehensive update on oil and gas policies in the last twelve (12) years. With respect to consi -stency of the policies of government on oil and gas concerns over the years, this study confirmed that there has been some consistency to a very large extent. For instance, the policy provisions of the National Gas Master Plan (NGMP) 2008 specifically on Domestic Gas Supply Obligation (DGSO) which w ere not fully met under the NGMP, have in turn been fully incorporated into the recent NGP 2017.

In retrospect, policy initiatives have not been deficient in Nigeria. A vital question is whether there has been any consist -ency whatsoever in the policies, as an obvious disconnect exists between the laws and policies governing the gas sector in Nigeria and some of the policies have remained untransmu- 
ted into laws. Omiyi [15] reported that deficient fiscal and gas pricing policies to boost investment, amongst other things, is responsible for the lingering problem of gas flaring in Nigeria. Adeniji et al [16] indicated that the Minister for Petroleum Resources is responsible for policy making in respect of the gas sector. They opined that government policy on the gas sector was usually deciphered from assertions that top government officers and organisations made in relation to the gas sector. With deference to the National Gas Policy, Adeniji et al noted that the NGP was Nigeria's principally validated gas policy, as it captured different aspects of government's relationship with the private sector and the roles of partakers in the gas chain and other ancillary matters.

Omorogbe [17] expounded on the correlation between policy, law and execution and noted that national legislation ought to align with enunciated policy declarations, and further argued that laws should follow policies and are crucial to the attainment or failure of such policies. Oyewunmi and Oyewunmi [18] examined the policy and regulatory perspectives on the issue of gas flaring in Nigeria's oil and gas sector. They indicated that the policy viewpoint was suggestive of the need for a fine-fettled environment. They further opined that putting in place a robust policy to regulate flaring activities of oil and gas producers in Nigeria was essential.

The Associated Gas Re Injection Act [19] prohibited gas flaring except with the approval of the Minister of Petroleum in writing. Section 3 (2) stated that:

Where the Minister is satisfied after Ja nuary 1,1984 , that utilisation or re injec tion is not appropriate or feasible in part icular field(s) then he may issue a certificate in respect of the company specify ing the terms and conditions as he may at his discretion choose to impose for the continued flaring of gas and permit the company to continue to flare gas in the particular field(s) if the company ays the prescribed fees as the Minister may from time to time prescribe.

Associated Gas Re Injection (Continued Flaring of Gas) Regulations 2004 dealt with the conditions for issuance of certificate for continued flaring of gas as follows:

a. Where more than 75 percent of the produced gas is effectively utilised or conserved.

b. Where the produced gas contains more than 15 percent impurities such as: $\mathrm{N}_{2}, \mathrm{H}_{2} \mathrm{~S}, \mathrm{CO}_{2}$ etc. which render the gases unsuitable for industrial purposes.

c. Where an on-going utilisation program is interrupted by equipment failure, provided such failures do not occur too frequently, from point of view of the Minister, and the eriod of interruption is not more than 3 mont hs).

d. Where the ratio of the volume of gas produced daily to the distance of the oil field from the nearest gas line or possible utilisation point is less than 50,000 standard cubic feet/ kilometre. e. Where the Minister in appropriate cases as he may deem fit, orders the production of oil from oil fields that do not satisfy any of the conditions specified in these regulations.

These regulations modified the present statute to offer halffinished insusceptibilities for flaring in definite situations. Another amendment additionally braced the provisions of the law and fortified an acceptable sum of 2 kobo for each 1000 standard cubic feet (scf) of gas flared. Afterwards, the fine was increased in 1988 to \$11dollars per $1000 \mathrm{scf}$ of gas flared. Thereafter, AGRA 2004 and AGR (Amendment) Act 2004 w ere enacted. The submission of detailed plans for gas utilisatio $\mathrm{n}$ by International Oil Companies involved in operations in the country, by virtue of the statutes was mandatory. The flaring of associated gas devoid of the inscribed authorisation of the Minister of Petroleum Resources (MPR) was outlawed by virtue of the statutes.

Flare Gas (Prevention of Waste and Pollution) Regulations 2018 were issued on June 28, 2018 and made available by the Federal Executive Council. These regulations remain pertinent to owners of oil fields, comprising borderline field owners. The intendment of the regulations was to make available a legal framework to fortify the environment against the effects of flaring of gas, avert unending discard of associated gas and generate societal and profitable paybacks from gas flared [20]. Flaring of gas is unambiguously outlawed and the regulations further presented reporting obligations, whereby gas producers were authorised to make flare gas data available at any given time, while similarly yielding once-a-month reports to the Department of Petroleum Resources [21]. The regulations assured the utilisation of flare gas by authorising the Minister to award certifications which would absolutely license holders of such permits to take flare gas for and as representatives of the Federal Government of Nigeria, from site(s) [22].

The Flare Gas (Prevention of Waste and Pollution) Regulations 2018 provide for $\$ 2$ for every 1,000 standard cubic fe et ( $\mathrm{scf}$ ) of gas flared payable by gas producers who account for over 10,000 barrels of oil production daily. However, producers who do not yield up to 10,000 barrels of oil production daily are to pay 50 cents per 1,000 scf of gas flared. A supplementary disbursement of $\$ 2.50$ for letdown to yield precise flare statistics, make available right of entry to flare sites and append signature on link pacts. In accordance with the reporting obligations introduced by the regulations, it is mandatory for gas producers to keep, maintain daily record of date, time, duration, rates, volume, gas source and flare type and yield the respective records once a month to DPR. The regulations cater for attractive punitive measures such as fines, custodial sentences, suspension of operations and or revocation of the functional license or permit. It is instructive to note that these measures, nonetheless, without incorporating market -based instruments, are not deterrent enough to eradicate flaring of gas by the oil and gas producers.

\section{B. Perception of the Challenges of Gas Flaring Policies in Nigeria}

The respondents' opinions were sought on the policy challenges encountered in the quest to reduce gas flaring in Nigeria. This section contained likert type responses, where $t$ he respondents were required to choose from one of the following options: (A) Strongly Agreed (B) Agreed (C) Neutral 
(D) Disagreed (E) Strongly Disagreed. The responses of the respondents are indicated below:

Table 2. shows that $75.0 \%$ of the respondents agreed on the inability of the gas flaring policies to enhance and promote gas utilisation in Nigeria, while $20.0 \%$ were neutral in their opinio n. On the other hand, no respondent disagreed, while $5.0 \%$ strongly disagreed. On the lack of consistency in the policies, $50.0 \%$ of the respondents agreed, while $35.0 \%$ of them were neutral and $15.0 \%$ of them disagreed. On the current gas regime not discouraging gas flaring, $55.0 \%$ of the respondents agreed, $20.0 \%$ of them were neutral and $25.0 \%$ of them disagreed. On the lack of infrastructural development in the gas sector, $80.0 \%$ of the respondents agreed while $15.0 \%$ of them were neutral and $15.0 \%$ disagreed. On the need for stiffer penalty to discourage gas flaring, $65.0 \%$ of the respond ents agreed while $10.0 \%$ were neutral and $25.0 \%$ disagreeed. On the absence of provision for revocation of license of companies engaging in gas flaring, $55 \%$ of the respondents agreed; $15.0 \%$ were neutral and $30.0 \%$ disagreed. On inadequate provision to address venting and monitoring of gas flaring, $55.0 \%$ of the respondents agreed, $35.0 \%$ were neutral while $10.0 \%$ disagreed. On inconsistency with global best practices $45.0 \%$ of the respondents agreed; $40.0 \%$ were neutral w hile $15.0 \%$ disagreed. On inadequate compensation for the communities, $65.0 \%$ of the respondents agreed; $25.0 \%$ werene utral; $5.0 \%$ disagreedwhile $5.0 \%$ strongly disagreed.

TABLE II. PERCEPTION OF RESPONDENTS ON THE CHALLENGES OF GAS FLARING POLICIES IN NIGERIA

\begin{tabular}{|l|l|l|l|l|}
\hline SA $(\%)$ & A $(\%)$ & N $(\%)$ & D $(\%)$ & SD $(\%)$ \\
\hline $9(45.0)$ & $6(30.0)$ & $4(20.0)$ & Nil & $1(5.0)$ \\
\hline $6(30.0)$ & $4(20.0)$ & $7(35.0)$ & $3(15.0)$ & Nil \\
\hline $8(40.0)$ & $3(15.0)$ & $4(20.0)$ & $5(25.0)$ & Nil \\
\hline $14(70.0)$ & $2(10.0)$ & $3(15.0)$ & $1(5.0)$ & Nil \\
\hline $9(45.0)$ & $4(20.0)$ & $2(10.0)$ & $5(25.0)$ & Nil \\
\hline $5(25.0)$ & $6(30.0)$ & $3(15.0)$ & $6(30.0)$ & Nil \\
\hline $7(35.0)$ & $4(20.0)$ & $7(35.0)$ & $2(10.0)$ & Nil \\
\hline $6(30.0)$ & $3(15.0)$ & $8(40.0)$ & $3(15.0)$ & Nil \\
\hline $9(45.0)$ & $4(20.0)$ & $5(25.0)$ & $1(5.0)$ & $1(5.0)$ \\
\hline
\end{tabular}

Source: Researcher's Questionnaire.

**Data was presented as numbers $(\%)$ of participants. Perception was assessed by assigning 5 to Strongly Agreed (SA), 4 to Agreed (A), 3 to Neutral (N), 2 to Disagreed and 1 to Strongly Disagreed (SD).

This study made a null hypothesis that there was a significant correlation between years of experience and the knowledge of oil and gas legal experts of National Gas Policy 2017.

TABLE III.CHI-SQUARE TESTS

\begin{tabular}{|c|c|c|c|}
\hline & Value & Df & $\begin{array}{l}\text { Asymptotic } \\
\text { Significance (2- } \\
\text { sided) }\end{array}$ \\
\hline $\begin{array}{l}\text { Pearson Chi- } \\
\text { Square }\end{array}$ & $2.826^{a}$ & 8 & .945 \\
\hline Likelihood Ratio & 3.551 & 8 & .895 \\
\hline $\begin{array}{l}\text { Linear-by-Linear } \\
\text { Association }\end{array}$ & .217 & 1 & .641 \\
\hline $\mathbf{N}$ of Valid Cases & 20 & & \\
\hline
\end{tabular}

a. 13 cells $(86.7 \%)$ have expected count less than 5 . The minimum expected count is .05 .

A chi-square test of independence was calculated comparing the years of experience of oil and gas legal experts and their knowledge of the National Gas Policy 2017. No significant relationship was found where

$$
\left(x^{2}(1)=2.826, \mathrm{p}>.05\right)
$$

Years of experience did not seem to influence their knowledge of the NGP 2017, as some with less years of experience were found to be more knowledgeable about the NGP than those $\mathrm{w}$ ith more years of experience. The result therefore rejected the null hypothesis assumed.

\section{DISCUSSION}

\section{A. Academic Qualification and Knowledge}

The criterion for admittance to legal practice in Nigeria in the field of law is a first degree in law from any university which offers courses prescribed and recognised by the Council of Le gal Education. The Council of Legal Education is answerable for the legal tutelage of individuals that seek to become members of the legal profession [23]. By virtue of their qualification, oil and gas legal experts can therefore express opinions based on the knowledge, skills, training and education they have acquired. The legal profession is grounded on proficiency in law and its applications [24]. Sound legal education to lawyers in training and legal practitioners in diverse sectors is very essential, cutting across national and international frontiers.

Age is a very significant demographic characteristic which has been used as one of the important variables in present day social science studies to classify individuals and elucidate variances amongst them. Global Education Monitor (GEM) reported that by cultivating knowledge, inculcating ideals and principles, education plays a pivotal role in helping people to abstain from naturally harmful practices [25]. It also brought $\mathrm{t}$ o the forefront, the correlation between advanced stages of education and articulating concern for the environment [26].

Research emphasised that people with additional education are predisposed to being more apprehensive about the environment while engaging in policy formulations and supportive of political decisions tilted towards the control and decline of greenhouse gases. This distinctive outlook is conjoint to oil and gas experts in Nigeria who are committed to reducing gas flaring to negligible levels.

Education is positively correlated with knowledge. Althou -gh, little or no studies have been conducted with reference to knowledge of gas policies and work experience of oil and gas legal experts globally, some studies have been conducted among school children (primary and secondary) to investigate the correlation between their knowledge and educational practices or programmes for environmental intervention.

Lieflander and Bogner [27] found no correlation between environmental knowledge and the attitude of the respondents within the framework of environmental intervention. Wang et al. [28] assessed the status of factors associated with residents' knowledge, attitudes and practices related to air pollution and respiratory health of children in Shangai. They found a significant correlation between the average knowledge scores and $t$ 
he parents' educational knowledge and average household income were two strong indicators on knowledge or awareness.

\section{B. Years of Experience and Knowledge}

Epistemology is a subdivision of philosophy which studies the foundation, nature, techniques and confines of human knowledge [29]. It is derived from the Greek word 'episteme' which means knowledge and 'logos' which means reason [30]. 'Experience" can be defined as the "direct observation of or participation in events as a basis of knowledge; the state of being affected by or gaining knowledge through direct observation or participation [31].' Technical and legal skills, as well as knowledge of the oil and gas industry are gathered during the engagement of oil and gas legal experts. With increased years of work experience, greater awareness of what the job entails is developed. Additionally, years of work experience gives practical first hand experience and there is an accrual of skills such as teamwork, decision making and problem solving, which are key to legal expertise.

Acquisition of experience over the years helps legal experts in the oil and gas sector to be more knowledgeable and skillful than those who don't have such experience in that given field. The knowledge of the policy framework among oil and gas legal experts was derived mainly from internet materials, oil and gas conferences and executive press releases related to the subject matter. Nevertheless, there appears to be an existing gap in knowledge with respect to the National Gas Policy 2017, as many, have little knowledge of the new market instruments within the Nigerian policy framework [32].

Locke [33] advanced a theory of epistemology which influenced the acuity of knowledge subsequently. His theory indicated that the entirety of an individual's knowledge solely originates from experience. He opined that experience entails two fold phases known as observations from peripheral objects (sensations) and inner maneuver or reflections of our minds. Locke argued that understanding is produced from sensations or reflections. However, research has shown that knowledge is no longer solely founded on experience but on concepts in the mind and experience. Whewell [34] advanced a theory of knowledge which suggested that knowledge is a fusion of both experience and our opinions and scrutiny of things in our surroundings. Hume [35] suggested a nexus between knowledge and experience, which was a total departure from Locke's views. He perceived the nexus materialised from a co mpendium of activities with similar facts garnered together in the mind resulting in a course of action. Whewell researched into the nature and composition of knowledge and this differed from Locke's work which was based on the origin of kno -wledge.

Other studies conducted have shown a nexus between knowledge and experience. Stanley and Pollard [36] examined the relationship between the years of experience and levels of knowledge, attitudes and self efficacy among the selected proffessionals. The study however found no significant correlation. Yunusa et al. [37] suggested that government should em -brace gas utilisation policy and there should be intensification of the penalty for companies engaged in gas flaring, while generating electricity from the flared gas. Nwanji [38] conside -red the legal and environmental outlook to gas flaring and stated that there was no explicit average and time interval for the implementation of government policies. Oluduro [39] stated that without a flawless legal framework, effectually containing national gas flaring issues might be tough, although the influence with Nigeria gas master plan and policy, have not been essentially identified in their productiveness.

\section{CONCLUSION}

The results indicate that the current policy framework with ref -erence to the gas sector are somewhat robust and promise to serve as a legislative relief to end gas flaring in Nigeria, if there is a paradigm shift, more towards market based approaches to environmental regulation, inspite of the challenges hitherto encountered with reduction of gas flaring in Nigeria [40]. The results of this survey provide valuable information on the knowledge, awareness and perception of the NGP 2017 among p urposively selected oil and gas legal experts in Nigeria.

Oil and gas legal experts play a pivotal role in the implementation of policies and improving the quality of positive environmental outcomes, yet many appear to have little knowledge of the new market instruments the policyframework in $\mathrm{Ni}$ geria is bringing on board to reduce gas flaring in Nigeria. Th e study can therefore become a basis for a national study eval uating the knowledge, awareness and perception of gas policies among oil and gas legal experts in Nigeria. To address the gap in knowledge therefore, the study suggests the possible inclusion of advanced education on market based instruments in environmental law curriculum subsequently.

\section{ACKNOWLEDGMENT}

The work is an excerpt from the author's Ph.D thesis (201 9). The author is grateful to Dr Bukola R. Akinbola of the Department of Jurisprudence and International Law, and Dr P. K. Oniemola of the Department of Commercial and Industrial Law, Faculty of Law, University of Ibadan, Nigeria, for their conscientious efforts in their capacity as Supervisor and Cosupervisor respectively, and also for their suggestions in respe -ct of this manuscript. Special appreciation also goes to all the Lawyers in Nigeria National Petroleum Corporation Headquarters, Abuja, Department of Petroleum Resources Headquarters, Lagos and private practitioners who participated in the study.

\section{REFERENCES}

[1] National Gas Policy Series 1 (Governance and Industry Structure) 20 September 2017, Available: http://www.olaniwun ajayi.net/blog/national-gas-policy-series-

i/ Accessed 4 February 2019.

[2] Nigeria: Oil and Gas Regulation 2019, Available: http://iclg.co $\mathrm{m} /$ practice-areas/oil-and-gas-laws-andregulations/nigeria\#tchaptercontent2/. Accessed 5 February 2019

[3] M. T. Okorodudu Fubara, Law of Environmental Protection: Materials and Text; Caltop Publications, Ibadan, Nigeria, 1998, pp. 399.

[4] U. E. Nwanji, "Gas flaring: legal and environmental perspective Nigerian Journal of Petroleum, Natural Resources and Environmental Law, 1, 1, 2009, pp. 26-45.

[5] E. Duruigbo, O. Wozniak, and M. Leighton, "Oil development in Nigeria: A critical look at Chevron's environmental and social responsibility", Environmental and Planning Law Review, 2, 2, 2005, pp. 123-134. 
[6] British Petroleum (BP) Statistical Review of World 2016, Available: http://www.bp.com/content/dam/bp/pdf -economics/statistical-review-2016/bp-statistical-reviewworld-energy-2016-full-report.pdf. Accessed 14 April 2017.

[7] G. Adeniji, S. Sipasi, K. Mesele, and G. Iroegbunam,

Regulation, London, Global Competition Review, 2006.

[8] O. Okunbor, "Re evaluating the development of the Nigerian gas industry", in Nigerian Gas Association's Business Forum, Lagos July 10 2016. Available: https://www.thenationonlineng.net/

25- nigerias-gas-reserve-utilised-says-shell-

chief/ Accessed 15 April 2017.

[9] United States Energy Information Administration. Nigeria remains a top gas flaring country says EIA. The Guardian June 1,

2016. Available: http://www.guardian.ng>businessservices>nige ria.Accessed 20 November 2016.

[10] National Gas Flare Commercialisation ProgrammeEnvironmental Effect. Available: http://www.ngfcp.gov.ng. Accessed 7 March 2019.

[11] OECD Guidelines for the Application of Economic Instruments in Environmental Policy 1991.

[12] Nigerian National Petroleum Corporation Monthly Financial and Operations Report September 2018. Available: http://www nnpcgroup.com/ Accessed 17 November 2018.

[13] Sk. J. Ali, Doctrinal Research in Law Field. Electronic copy Available: http://ssrn.com/abstract $=2254461$

Smith, J. M., What is legal doctrine? On the aims and methods of legal dogmatic research. Maastricht European Private Law Institute working Paper No. 2015/06. Available: http://ssrn.com/ abstract $=2644088$. Accessed 15 May 2016.

[14] J. Nieuwenhuis, First Steps in Research, M. Kobus, Ed, retoria: Van Schaik Publishers, 2007.

[15] B. Omiyi, "Shell Nigeria corporate strategy for ending gas flaring", Seminar on gas flaring and poverty alleviation, Oslo, June 18-19 2001, pp. 1-13.

[16] Op. cit. Adeniji et al.

[17] Y. Omorogbe, "Promoting Sustainable Development through the Use of Renewable Energy: The Role of the Law, in D.

Zillman, C. Redgwell, Y. Omorogbe, and L. K. Barrera Hernandez, Eds, Beyond the Carbon Economy: Energy Law in Trans ition, New York: Oxford University Press Inc.2008, pp. 39-59.

[18] O. A. Oyewunmi, and A. E. Oyewunmi, "Managing Gas Flaring and Allied Issues in the Oil and Gas Industry: Reflections on Nigeria", Mediterranean Journal of Social Sciences 7, 4,

2016, pp. 643-648.

[19] Associated Gas Re-

Injection Act Cap A25 Laws of the Federation of Nigeria 2004.

[20] Regulation 1 (a) -

(d) Flare Gas (Prevention of Waste and Pollution) 2018.

[21] Regulation 16 and 17 Flare Gas (Prevention of Waste and ollution) 2018.

[22] Regulation 2 (2) Flare Gas (Prevention of Waste and Pollution) 2018.

[23] Section 1 (2) Legal Education (Consolidation etc.,) Act Cap

L10 Laws of the Federation of Nigeria 2004.

[24] Legal Profession: Britannica.com. Available: https://www.brita nnica.com/topic/legal-profession/. Accessed 30 January 2019.

[25] Global Education Monitoring Report United Nations Educational, Scientific and Cultural Organisation (UNESCO). Available https://www.gemreportunesco.wordpress.com. Accessed 30

January 2019.

[26] ibid

[27] A. K. Lieflander, and F. X. Bogner, "Educational impact on the relationship of environmental knowledge and attitudes", Environmental Education Research, 24, 4, 2018, pp. 611-624.

[28] R. Wang, Y. Yang, R. Chen, H. Kan, J. Wu, K. Wang, J.

Maddock, and Y. Lu, "Knowledge, attitudes and practices $(\mathrm{K}$ AP) of the relationship between air pollution and children's resp iratory health in Shanghai, China", Internati- onal Journal of Environmental Research and Public Health, 12, 2015, pp. 1834-1848.

[29] Epistemology Definition, nature, problems and history Britannica. Available: https://www.britannica.com/topicepsistemology Accessed 4 March 2019.

[30] ibid

[31] Merriam Webster Definition of Experience. Available:https://w ww.merriamwebster.com/dictionary/experience/.Accessed 4

March 2019.

[32] T. O. Jolaosho, Legal Framework for Gas Flaring Reduction in Nigeria, University of Ibadan, Ibadan, Nigeria, Doctoral Thesis, 2019.

[33] J. Locke, An Essay Concerning Human Understanding, P. Kenneth Winlder Book II.1689. Available: www.earlymoder $\mathrm{n}$ texts.com/assets/pdfs/locke1690book2.pdf Accessed 22

May 2019.

[34] W. Whewell, Theory of Scientific Method, Robert E. Butts Ed. Indianapolis, Hacket Publishing Company, 1989.

[35] D. Hume, The Oxford Companion to Philosophy, T. Honderich Ed., Oxford and New York, Oxford University Press, 1995.

[36] M. Stanley, and D. Pollard, "Relationship between knowledge, attitudes and self efficacy of nurses in the management of pediatric pain”, Pediatric Nurse, 39, 4, 2013, pp. 165-171.

[37] N. Yunusa,I. T. Idris, A. G. Zango, and M. U. Kibiya, "Gas

flaring effects and revenue made from crude oil in Nigeria", nternational Journal of Energy Economics and Policy, 6, 3, 16, pp. 617-620.

[38] Op. cit. Nwanji.

[39] O. F. Oluduro, "The legal implications of gas flaring on $\mathrm{cl}$ imate change in Nigeria," Journal of Law, Policy and balisation, 29, 2014, pp. 168-175.

[40] Op. cit. Jolaosho. 